\title{
The effect of modular education on school dropout
}

Citation for published version (APA):

Mazrekaj, D., \& De Witte, K. (2020). The effect of modular education on school dropout. British Educational Research Journal, 46(1), 92-121. https://doi.org/10.1002/berj.3569

Document status and date:

Published: 01/02/2020

DOI:

10.1002/berj.3569

Document Version:

Publisher's PDF, also known as Version of record

Document license:

Taverne

\section{Please check the document version of this publication:}

- A submitted manuscript is the version of the article upon submission and before peer-review. There can be important differences between the submitted version and the official published version of record.

People interested in the research are advised to contact the author for the final version of the publication, or visit the DOI to the publisher's website.

- The final author version and the galley proof are versions of the publication after peer review.

- The final published version features the final layout of the paper including the volume, issue and page numbers.

Link to publication

\footnotetext{
General rights rights.

- You may freely distribute the URL identifying the publication in the public portal. please follow below link for the End User Agreement:

www.umlib.nl/taverne-license

Take down policy

If you believe that this document breaches copyright please contact us at:

repository@maastrichtuniversity.nl

providing details and we will investigate your claim.
}

Copyright and moral rights for the publications made accessible in the public portal are retained by the authors and/or other copyright owners and it is a condition of accessing publications that users recognise and abide by the legal requirements associated with these

- Users may download and print one copy of any publication from the public portal for the purpose of private study or research.

- You may not further distribute the material or use it for any profit-making activity or commercial gain

If the publication is distributed under the terms of Article $25 \mathrm{fa}$ of the Dutch Copyright Act, indicated by the "Taverne" license above, 


\title{
The effect of modular education on school dropout
}

\author{
Deni Mazrekaj $^{\mathrm{a}, \star}$ (D) and Kristof De Witte ${ }^{\mathrm{a}, \mathrm{b}}$ \\ ${ }^{a}$ Leuven Economics of Education Research (LEER), KU Leuven, Belgium \\ ${ }^{\mathrm{b}}$ United Nations University - Maastricht Economic and Social Research Institute on \\ Innovation and Technology (UNU-MERIT), Maastricht University, The Netherlands
}

\begin{abstract}
Modular education refers to the division of conventional courses into smaller components or modules. Each module enables students to obtain a partial certificate that can be combined into a qualification. This article evaluates whether modular education, which is widely used in secondary and tertiary education, has been effective in reducing school dropout. For this purpose, the study exploits a policy change in the Flemish Community of Belgium, which recently introduced modular education for some programmes. Using a difference-in-differences framework with diverse adoption dates per school, the results indicate that modular education may significantly reduce school dropout by 2.5 percentage points, with the largest effects on foreign origin students. Therefore, modular education is likely to be an effective policy to tackle school dropout and reduce the ethnic attainment gap. Additionally, students enrolled in modular education are more likely to be employed and to incur higher earnings on the labour market.
\end{abstract}

Keywords: school dropout; modular education; ethnic minorities; labour market outcomes; difference-in-differences

\section{Introduction}

School dropout is believed to instigate various undesirable social outcomes such as crime (Merlo \& Wolpin, 2015; Cook \& Kang, 2016), teenage pregnancy (Black et al., 2008), unemployment and employment instability (Li, 2006; Cairo \& Cajner, 2018), lower wages (Devereux \& Hart, 2010; Dolton \& Sandi, 2017), lower health (Groot \& van den Brink, 2007), lower life expectancy and lower overall happiness (Oreopoulos, 2007; Oreopoulos \& Salvanes, 2011). Similar social outcomes at the individual level may translate into a societal burden. Eurofound (2012) puts the annual cost of school dropout in the European Union (EU) at approximately 100 billion euros, which is almost $1.1 \%$ of gross domestic product (GDP). ${ }^{1}$

Over the last two decades, both the EU and the USA have launched policy initiatives to reduce school dropout. The EU set out objectives in the 'Europe 2020' strategy with the aim of reducing the school dropout ratio to $<10 \%$ by 2020 . Similarly, the

\footnotetext{
ॠCorresponding author. Leuven Economics of Education Research (LEER), KU Leuven, Naamsestraat 69, 3000 Leuven, Belgium. E-mail: deni.mazrekaj@kuleuven.be

The data for this study are protected by a confidentiality agreement and we are precluded from sharing the data with others. Interested readers can contact the corresponding author for information on how to obtain access to the data. We would be happy to provide assistance and Stata code to replicate the results of this paper.
} 
'Dropout Prevention Act' introduced in the USA in 2004 grants funding for dropout prevention programmes aimed at reducing the school dropout rate. However, school dropout continues to be a major socioeconomic challenge of the current knowledge economy. According to Eurostat (2017), there were more than 5.6 million school dropouts $(11 \%)$ in the EU in 2015 within the 18-24 age group. The corresponding statistics for school dropouts without a valid school-leaving credential ${ }^{2}$ in the USA stand at 2.5 million (5.9\%) within the 16-24 age group (US Department of Education, 2017).

In this article, we estimate the causal effect of modular education on high school dropout and provide evidence on the association between modular education and labour market outcomes. Modular education is already prevalent during tertiary education in most of the Organisation for Economic Co-operation and Development (OECD) countries. Lately, modular education has been gaining popularity as a dropout prevention policy in secondary education. ${ }^{3}$ Modular education divides the educational programme into smaller autonomous components or modules that bundle a set of learning outcomes (knowledge, skills and/or competences). With the completion of each module, a partial certificate is granted which can subsequently be used in the labour market to gain employment. Completion of all the modules in an education programme results in obtaining the traditional educational qualification. Although the learning objectives and the material taught through the modules remains analogous to the conventional linear education programme, students enjoy increased autonomy to choose among the modules. ${ }^{4}$

Previous studies that analysed modular education focused mainly on general or pre-university education. The evidence on the association between modular education and student achievement is mixed. In a descriptive study, Taverner and Wright (1997) compared students who took A-levels in the UK through modular and linear education. They found that students in modular education scored half a grade higher on A-level mathematics. By contrast, McClune (2001) found that students who took A-levels in Northern Ireland through modular education performed worse in physics than students who took the course through linear education. Finally, the results obtained by Vidal Rodeiro and Nàdas (2012) suggest that the association of modular education and student achievement depends on the course. They observed that modular education was positively associated with General Certificate of Secondary Education (GCSE) grades in mathematics, but no association was found in English.

Although these studies provide important evidence on the association between modular education and student achievement in general and pre-university education, they do not consider vocational education. Nonetheless, most students actually drop out from vocational education (European Commission, 2013). Moreover, dropout from vocational education is less unequivocally negative and more multi-dimensional than for general and pre-university education (De Witte et al., 2013). This is because students in vocational education are trained for a specific profession and to perform specific tasks. Therefore, students may drop out of school because they have an opportunity to work in the profession they are trained for. An interesting strand of literature compared the dropout risk and subsequent labour market outcomes of students in general and in vocational education (e.g. Dickson \& Harmon, 2011; Balestra \& Backes-Gellner, 2017; Mazrekaj et al., 2019). For instance, in Flanders, Belgium 
(the region studied in this article), Mazrekaj et al. (2019) found that the labour market outcomes of students with and without a diploma differ depending on the education track a student followed in secondary education (general or vocational education). Thus, as vocational education students often have different observed and unobserved characteristics than students in other educational tracks (Chankseliani et al., 2016), and as dropout is more multi-dimensional in vocational education, it is unclear whether the results obtained in previous studies for general and pre-university education also hold for vocational education.

To the best of our knowledge, only two studies compared student outcomes in modular and linear programmes in vocational education. Pelleriaux and De Rick (2004) analysed a small pilot modularisation project in 2000 that included 1,360 vocational education students in 40 schools in Flanders, Belgium. They found that the probability of high school dropout was twice as high in linear education as in modular education. The second study that compared student outcomes in modular and linear programmes in vocational education is a descriptive study by Grebe and Ekert (2017) in Germany. They found that pre-vocational education students who were in modular education were more likely to progress to vocational education than pre-vocational education students in linear education. Although these studies provide first evidence on the potential effect of modular education on student outcomes in vocational education, they suffer from an important limitation. Namely, all the studies conducted about modular education, regardless of the track, suffer from omitted-variables bias and therefore produce only descriptive statistics or correlational estimates, rather than causal effects. Consequently, due to selection bias arising from students choosing a modular rather than a linear programme, these estimates may be misleading.

Using a unique administrative panel dataset from the Flemish Ministry of Education, we contribute to the literature in three ways. First, we study the effect of modular education in vocational education. As mentioned above, this is interesting as dropout in vocational education is multi-dimensional and vocational education students typically come from disadvantaged backgrounds. Therefore, they are most prone to high school dropout. Second, we provide the first causal estimates of the impact of modular education on high school dropout rate. Using a difference-in-differences framework, we exploit the variation induced by the Flemish decree of 10 July 2008 , which introduced modular education for a set of vocational programmes at risk of school dropout. ${ }^{5}$ More specifically, the Flemish Ministry of Education provided a specific list of vocational programmes on their website which were to become modular (Flemish Ministry of Education, 2015). Consequently, starting from school year 2008-2009 and during the following two school years 2009-2010 and 2010-2011, most schools $(89 \%)$ have been offering both types of education programme. ${ }^{6}$ Within those schools that offered both types of education programme, we compare student dropout rates in modular education with student dropout rates in linear education through different years of adoption. As a last contribution, we offer first estimates on the association between modular education and subsequent labour market outcomes. To the best of our knowledge, no study has quantitatively related modular education to labour market outcomes before.

The study thus addresses two main research questions: 'Does modular education causally reduce high school dropout in vocational education?' and 'Is modular 
education correlated with higher labour market outcomes in vocational education?' As part of these main research questions, we also aim to answer whether modular education has a heterogeneous effect on high school dropout and on students' labour market outcomes by students' gender and origin.

The remainder of the article is structured as follows. The 'Background' section informs about the Flemish education system, with particular emphasis on the policy reform that introduced modular vocational education. The 'Theoretical mechanisms' section outlines potential theoretical mechanisms through which modular education may influence high school dropout and labour market outcomes. The 'Data' section formulates the difference-in-differences model. The 'Difference-in-differences' section describes the data and sample restrictions. The 'Results' section presents the estimates of the effect of modular education on diploma attainment, addresses the parallel trends assumption (PTA) and concludes with internal validity testing of the estimates with a sensitivity, placebo and exact matching analysis. This section also presents evidence of the effect of modular education on labour market outcomes. The article ends with a discussion of the results and a policy conclusion in the 'Discussion' section.

\section{Background}

\section{Flemish education system}

The Flemish education system provides for compulsory education beginning at the age of 6 and continuing until the age of 18. Both primary (grades 1-6) and secondary (grades 7-12) education programmes last for 6 years each. ${ }^{7}$ At the age of 12 , students enroll into a secondary education programme based on a tracking system including four principal education tracks emphasising general, technical, vocational and arts education. Students are not allocated to a particular track based on standardised cognitive tests or catchment areas. At the end of primary education, they choose a school that offers one or more tracks of interest based partly on the advice given by the students' primary school teacher and partly on the parents' own aspirations. General education ( $A S O)$ prepares students for tertiary education, while arts education (KSO) combines general education with arts. Technical education (TSO) is focused on imparting technical knowledge that may complement tertiary education or may lead to immediate start in a professional career after graduation. Lastly, vocational education (BSO) focuses on professional life and prepares students for a certain occupation. ${ }^{8}$

Each track in secondary education is divided into three stages. The first stage (grades 7 and 8 ) includes a common core curriculum to provide time for students to think about a particular track to follow in the second stage. Thus, in the first stage, there are officially no tracks and in grade 7, the curriculum is the same for all tracks, except for five lessons per week. These five lessons depend on the tracks offered by a particular school in the next two stages (Van Houtte \& Stevens, 2015). As previously mentioned, students have already chosen a school that offers one or more tracks of interest. In the second stage (grades 9 and 10), students choose a particular programme within a track. In vocational education (the focus of this study), students can choose between programmes such as construction, wood, textiles, sales, food, hair 
care, jewellery and others. In the third and last stage (grades 11 and 12), students usually continue with the programme chosen in the second stage. Nonetheless, some programmes split further into multiple programmes; for instance, the 'jewellery' programme in the second stage becomes 'diamond processing', 'jewellery creation', 'gold and jewellery' and 'clockwork repair' in the third stage.

Students in general, technical and arts education who successfully complete the second year in the third stage (grade 12) receive a secondary education diploma. These students can either enter the labour market or continue their studies in tertiary education. In tertiary education, students can choose between an Academic Bachelor's programme at a university, a Professional Bachelor's programme at a university college or an Associate degree programme at the Centre for Adult Education (CVO). In contrast to students in general, technical and arts education, students in vocational education who successfully complete grade 12 receive a certificate. Although this certificate signifies the successful completion of a vocational programme and gives students access to enroll into higher vocational education at a CVO, it prevents students from enrolling into tertiary education at a university or a university college. If vocational education students wish to continue studying in either of these two institutions, they have to enroll into an additional specialisation year. Students who successfully complete this additional year receive a secondary education diploma as in other tracks.

The average high school dropout rate in Flanders was $11 \%$ in school year 20162017 (Flemish Ministry of Education, 2019). The highest dropout rate is found in vocational education $(17 \%),{ }^{9}$ followed by arts education $(12.8 \%)$ and technical education $(7.4 \%)$. The lowest school dropout rate was recorded for general education $(2.4 \%)$. Upon graduation, most general education students enter tertiary education $(94.6 \%)$, followed by arts education $(84.9 \%)$ and technical education students $(77.1 \%)$. By contrast, it is rather uncommon for vocational education graduates to continue their studies in tertiary education, with only $21 \%$ enrolling for a tertiary education programme.

Given the highest dropout rate and the lowest enrolment into tertiary education, the vocational education track is perceived to be the least prestigious track (Van Houtte \& Stevens, 2015). Nonetheless, students can freely choose any track in Flanders, given that the Flemish education system does not hold entrance exams for secondary education. This often results in many students degrading between tracks during the first years of secondary education. Nonetheless, it is uncommon for students to degrade from the general education track all the way to the vocational education track. Further, it has been observed that mobility to a higher track is in practice rather exceptional in the case of vocational education.

\section{Policy reform in vocational education}

Before the introduction of modular education in 2008, all secondary education students followed a traditional linear education programme regardless of track. Under the linear education system, the programme consisted of several courses given each year, all of which had to be successfully completed before receiving a credential for the programme at the end of secondary education. For instance, a student wishing to 
become a hairdresser would follow the linear vocational programme 'hair care' in the second and third stage of vocational education and would have to complete all eight courses in this programme ${ }^{10}$ given each year to receive a vocational education certificate. Any student dropping out of secondary education before the completion of each of the courses would therefore be forced to enter the labour market without a credential for the completion of the education programme.

In 2008, however, the Flemish government started implementing modular education in the second (grades 9 and 10) and third (grades 11 and 12) stages of secondary vocational education. The main goals of the policy were to reduce school dropout and decrease labour market mismatch by departing from the conventional all-ornothing education programmes based on large linear courses only awarding credentials after the successful completion of the entire programme. Modular education consists of many small modules in each programme instead of several large courses. These modules start at any point during a school year and typically last for a period of 12-21 weeks. Students in modular education then choose modules that best fit their interests. For instance, the linear programme 'hair care' is now divided into many small modules such as 'hair styling', 'hair colouring' and 'hair salon management'. In this way, students are given the freedom to choose their educational path, since a student wishing to become a hairdresser for a large hairdressing company would not choose the module 'hair salon management', while a student who aims to open his own hair salon would. Moreover, the completion of each module leads to a credential. This credential has value in the labour market. A combination of several credentials eventually leads to a formal qualification. ${ }^{11}$ Although the organisation of systems is different, the learning objectives and materials taught under the different education systems are analogous, as defined in the standards set by the central government. Moreover, the teachers who taught linear education programmes typically also taught the newly constructed modules under the modular education programmes. ${ }^{12}$

The reform was implemented for all schools offering vocational education in Flanders. The Ministry of Education provided a specific list of $39 \%$ of vocational programmes that were to become modular, ${ }^{13}$ based on the high dropout rates in these programmes (therefore, not based on the dropout trends, see the section 'PTA and treatment effect by school year'). These programmes were all situated in the second and third stages of vocational education. Therefore, modular education was not introduced gradually by grade, but rather immediately in grades 9-12 at the same time. The exact modules were provided by the Ministry, highlighting the content of each module as well as the time duration for each module (Flemish Ministry of Education, 2015). The implementation of the reform was monitored by the government through the education inspectorate and schools received no additional funding.

This process of modularisation started in school year 2008-2009 and stopped in school year 2010-2011. By then, 89\% of the schools were offering both modular and linear programmes. Some of the schools, however, offered only modular programmes $(2 \%)$ or only linear programmes $(9 \%)$. This was because the list of programmes was determined by the Ministry. Therefore, some schools simply did not offer any of the listed programmes before the reform, while other schools only offered the listed programmes before the reform. After the reform, the former schools would continue offering only linear programmes, while the latter schools would be offering only 
modular programmes. In Table A1 in Appendix A, we compare schools that offered only linear education or only modular education with schools that offered both linear and modular education for several school characteristics. We find that schools that offered only linear education were typically smaller and comprised mostly socioeconomically advantaged students who were less likely to drop out compared to schools that offered both linear and modular education. By contrast, schools that offered only modular education were typically larger and comprised mostly socioeconomically disadvantaged students at risk of school dropout. This also suggests that modular education was mainly used in programmes with more disadvantaged students who typically have lower diploma attainment, as was intended by the policy.

In our analysis we compare, within schools, students in modular education with students in linear education before and after the reform. In other words, the variation stems from the difference in dropout rates between students in modular and in linear education before and after the reform, within schools. Therefore, we focus on the majority of schools that offered both linear and modular education, and exclude schools that offered only linear or only modular education. Although this slightly reduces the external validity of the estimates, $89 \%$ of the schools offered both types of education.

In almost half of the schools that eventually offered both types of education, modular education was introduced during the school year 2008-2009 (45\% of schools). In school year 2009-2010, modular education was implemented by 36\% of schools. The remaining $19 \%$ of schools implemented modular education during the school year 2010-2011. No other significant reforms were implemented during this period. If a student was enrolled in a linear programme in school year 2007-2008 and the school implemented modular education in school year 2008-2009 for this programme, the student would be following a modular programme in school year 20082009. Given that the list of programmes that were imposed by the Ministry to be modular did not change over time, the difference in implementation rate is due to schools introducing modular education at a different rate. In Table A2 in Appendix A, we present school characteristics per implementation school year. It appears that the implementation started in larger schools with a higher share of disadvantaged students, which are typically the schools with the highest dropout rates. This is intuitive given that the intervention aimed to reduce school dropout. However, this does not threaten the internal validity of the analysis as we estimate the effect of modular education on school dropout within schools.

Theoretically, it is possible for a student to switch from a linear programme to a modular programme after the reform and vice versa. If high-performing students were more likely to switch from a linear to a modular programme, the effect of modular education on school dropout would be overestimated, while the reverse is true if the students who switched were low-performing students. In practice, however, movement between modular and linear programmes is uncommon in vocational education. Our data indicate that only $3.22 \%$ of students who were first enrolled in a linear programme later switched to a modular programme or vice versa. Therefore, sorting after first enrolment is unlikely to be an issue. Nonetheless, as a robustness test in the section 'Alternative specifications', we perform the analysis with students who switched between the two education types excluded. 
Modular education applied to incumbent students already enrolled in the second or third stage as well as to new entrants. Upon successful completion of the first stage, a student can opt for a modular programme in the second stage. Thus, although sorting after first entry is unlikely to be an issue as stated above, sorting may occur at the moment that the programme choice has to be made for the first time, namely at the end of the first stage. Students who would have chosen one system in the absence of the reform might now make another choice because of the reform. This is, however, unlikely to be the case in the Flemish setting. First, our data indicate that the share of students in (to become) modular education has remained stable throughout the school years at about $46 \%$ before and after the introduction of modular education, which started in school year 2008-2009 (see Figure A1 in Appendix A). Second, as students are already enrolled in the first stage, schools in Flanders cannot be selective in whom they admit to participate in the modular system in the second stage. Students can freely choose a programme as long as they successfully completed the first stage. Lastly, in the section 'Alternative specifications', we conduct a placebo test in which we compare students enrolled in linear vocational education to students in technical vocational education which was also linear. If sorting was taking place, the composition change of students in linear vocational education should have induced a placebo treatment effect relative to those in technical education. We find that this is not the case. Consequently, we conclude that sorting of new entrants is unlikely to be driving our results.

\section{Theoretical mechanisms}

\section{Modular education may influence high school dropout}

Most countries have introduced modular education primarily based on the premise that modular education reduces high school dropout rate. ${ }^{14}$ This reduction in high school dropout as a result of modular education is assumed based on four theoretical mechanisms. First, students may enjoy increased flexibility under the modular system as they have more autonomy in choosing modules (Ertl, 2000). Especially in vocational education, students are overwhelmingly heterogeneous. They range from students who have a clear picture of the career they want to pursue to students who have no clear idea of their working future, and from low- to high-ability students (De Bruijn \& Howieson, 1995; Chankseliani et al., 2016). It is argued that modular education allows students to choose modules that provide higher intrinsic motivation, enabling them to choose a career path based on their abilities. Moreover, as programmes include smaller modules that typically last a few months, switching within modular programmes may be easier than switching within linear programmes. This may help students who feel they made a wrong initial choice to get back on the right educational path. As a result, the flexibility of modular education may reduce the risk of high school dropout.

A second theoretical mechanism through which modular education may reduce high school dropout is partial certification. In particular, students in modular education obtain a partial certificate after the completion of each module. This partial certification may facilitate the experience of success by students and increased feedback 
on a regular basis, which in turn provides increased extrinsic motivation to students to continue the pursuance of a high school degree (Hattie \& Timperley, 2007). For instance, Hodgson and Spours (2003) observed that students generally like modular courses and use feedback from partial examinations to adapt to assessments in other modules.

Further, it can be argued that it is easier to accomplish a series of small, short-term goals such as the completion of each module than one complex, long-term goal such as the attainment of a diploma (Locke \& Latham, 2002). Moreover, as modules are typically short and are assessed at the end of the module, students in modular education have an incentive to work throughout the entire school year. By contrast, students in linear education may reduce their effort in the beginning of the school year and increase their effort towards the end to improve their grades (Hayward \& $\mathrm{McNi}$ choll, 2007). For some students, however, this strategy may lead to poor results. Therefore, setting small, short-term goals through modular education may lead to increased overall effort and a reduced risk of high school dropout.

Finally, modules are easier to update than conventional courses. Consequently, it is argued that students in modular education are less influenced by economic fluctuations than students in linear education (Pilz et al., 2018). To the extent that these economic fluctuations increase high school dropout, students in modular education may leave education at a lower rate.

The previous four theoretical mechanisms may lead to a reduction in the high school dropout rate through desirable mechanisms. However, modular education may also reduce high school dropout through an arguably undesirable mechanism. Specifically, modular education may lead to fragmentation of knowledge due to students purposely choosing easier modules in order to obtain a high school diploma (Hayward \& McNicholl, 2007). This problem was recognised by Rust (2000), who found that pupils tend to enroll into modules just to 'tick them off' instead of gaining additional knowledge about a topic. Moreover, Hennessy et al. (2010) estimated that $46.4 \%$ of the surveyed students opted for a particular module because they thought it would be an easy option. Although this theoretical mechanism predicts that modular education may reduce high school dropout, it may also lead to a drop in educational quality.

Four other theoretical mechanisms predict that modular education may increase high school dropout. Similar to the mechanism above, modular education may lead to fragmentation of knowledge due to students being provided with insufficient or partial information and thus choosing poorly compatible modules. As a result, students may have a poor overview of subjects and a weak connection between different areas of knowledge, which may decrease their motivation for continuing education (Wilde et al., 2006). Consequently, students may choose to drop out of high school.

A second theoretical mechanism through which modular education may exacerbate high school dropout is increased examinations. Specifically, modular education may increase teacher workload due to increased examinations and reduce teacher quality. Surveying Welsh science teachers, Thomas (1993) found that $95 \%$ of teachers agreed with the proposition that 'illness of pupils and teachers causes greater problems under the modular system than under previous systems'. Moreover, $83 \%$ were in agreement with the proposition that 'it is difficult to complete the work contained in a module in 
the time allocated'. As a result, teachers may resort to teaching to the test under the modular system, leading to a loss of learning due to exam preparation and exam taking at the end of each module (Priestley, 2003). This test-oriented approach may result in test anxiety, subsequent student demotivation and ultimately high school dropout (Cassady \& Johnson, 2002).

Further, it is possible that modular education increases high school dropout due to the 'pull' mechanism of the labour market. Students may acquire certain skills (and partial certificates) through specific modules and deem them sufficient to enter and reside in the labour market. In this way, students may complete a set of modules which they find important for a particular job, but they may not necessarily obtain a high school diploma. In addition, students may leave school because they have an opportunity to work in the profession they are trained for. Consequently, this may increase high school dropout. However, it is important to note that this increase in high school dropout may not necessarily be bad for students. Students who would have left school regardless may actually benefit from a modular system as they would now have acquired a specific set of skills which they wouldn't have acquired under a linear curriculum. Thus, although modules may increase high school dropout through this 'pull' mechanism of the labour market, an increased match between education and the labour market, combined with the acquired skills through modules, may actually be positive for these school dropouts. This is why it has been argued in the literature that dropout in vocational education is less unequivocally negative and more multi-dimensional (De Witte et al., 2013). Finally, as mentioned above, it is argued that students in modular education may be less influenced by economic fluctuations than students in linear education, due to increased adaptability of modules to economic fluctuations. If a specific economic shock increases (or decreases) high school dropout, then modular education may lead to a lower (or higher) probability of high school dropout, as modules can be adapted accordingly.

\section{Modular education may influence labour market outcomes}

Modular education may increase students' labour market outcomes in three ways. First, as stated previously, modular education may decrease high school dropout. In turn, lower high school dropout may reduce the probability of unemployment and employment instability (Li, 2006; Cairo \& Cajner, 2018) and increase the probability of receiving higher wages (Devereux \& Hart, 2010; Dolton \& Sandi, 2017). Therefore, modular education may increase students' labour market outcomes through its influence on high school dropout.

Modular education may also increase students' labour market outcomes through partial certification. As described by the signalling theory of Spence (1973), employers pay a wage premium to employees with a high school diploma over employees without a high school diploma. Not having a diploma, therefore, signals a lack of competence to a potential employer. Through partial certification obtained after the completion of each module, even the dropout students without a complete high school diploma can signal their obtained competences. ${ }^{15}$ Consequently, modular education may lead to higher employment and earnings. Finally, signalling through partial certification under a modular system may also provide a better match between 
the employer and the employee. This may lead to high satisfaction of employees with their jobs, subsequent higher productivity and higher earnings (Somers et al., 2019).

These potential benefits of modular education notwithstanding, modular education may also decrease students' labour market outcomes in a similar way. First, modular education may decrease students' labour market outcomes through its influence on high school dropout. Analogous to the argument above, modular education may increase high school dropout and subsequently increase the probability of unemployment and employment instability (Li, 2006; Cairo \& Cajner, 2018) and decrease the probability of receiving higher wages (Devereux \& Hart, 2010; Dolton \& Sandi, 2017). Second, as stated previously, students may choose poorly compatible modules either inadvertently or on purpose and therefore fragment their knowledge by acquiring occupation-specific skills which are unrelated. This fragmentation may lead to a larger mismatch between the employee and the employer, subsequent lower productivity and lower earnings (Somers et al., 2019). In sum, the influence of modular education on students' labour market outcomes depends mainly on its influence on high school dropout and on the match between employee and employer.

\section{Data}

\section{Dataset construction}

Data for this study come from administrative records collected by the Flemish Ministry of Education. We observe enrolment in primary and secondary education of all students in Flanders from school year 2005-2006 until school year 2011-2012. Therefore, we observe three pre-treatment school years (2005-2006, 2006-2007 and 2007-2008) and four post-treatment school years (2008-2009, 2009-2010, 20102011 and 2011-2012). Moreover, this administrative panel dataset also includes information on the programme followed and the qualification obtained. To determine whether a programme would become modular, we consulted the list of modular programmes provided by the Flemish Ministry of Education on their website (Flemish Ministry of Education, 2015). In addition to school information, we also observe quarterly labour market outcomes from Q3 in 2011 to Q4 in 2013 (earnings and employment) for school leavers (graduates and school dropouts) in school year 20102011.

To study the effect of modular education on high school dropout, we restrict the sample in three ways. First, we focus solely on students in full-time secondary vocational education. Students in part-time vocational education have been removed from the analysis. As almost all part-time vocational education programmes have been modularised, including these students would lead to a comparison of students from part-time modular education with students from full-time linear education. This is, however, not a proper comparison, as students in part-time vocational education differ significantly from students in full-time vocational education in Flanders. In particular, they typically have a lower socioeconomic background and higher dropout rates and would be biasing our estimates downward (De Witte \& Mazrekaj, 2016). Therefore, to avoid endogeneity issues arising from unobserved heterogeneity bias, we have removed these students from the analysis. 
As a second sample restriction, we do not include about 40 schools which participated in the pilot scheme that introduced modular vocational education in 2000 . Given that these schools were already modular in the experimental phase and our dataset starts in school year 2005-2006, we would have no pre-treatment observations to analyse for these schools. As a result, we cannot perform a difference-in-differences strategy for these schools (see the 'Difference-in-differences' section). Although this restriction reduces the external validity of the results slightly, our dataset remains large, including information for 400 schools. Lastly, because we estimate the effect of modular education on high school dropout, students who were in the process of obtaining a credential have been removed from the analysis as they have no outcome.

\section{Variables construction}

Modular education. The policy variable of interest is modular education. We construct this variable as an indicator having value 1 if a student was enrolled into a modular programme in a given school after the policy change, and 0 otherwise. In an additional estimation (see the 'Difference-in-differences' section), we also consider interactions between modular education and indicators for school years. This allows us to estimate how differences between modular and linear education evolve over time, as well as to test whether the PTA is likely to hold (see the section 'PTA and treatment effect by school year').

Outcome variables. The outcome of interest is a high school diploma. This variable is measured as an indicator having value 1 if a student obtained a vocational education qualification certificate, and 0 otherwise (if the student was a high school dropout). We define a high school diploma as a vocational education qualification certificate that students obtain at the end of the second year of third stage, in grade 12 . This certificate is used by the Flemish Ministry of Education to distinguish between high school graduates and high school dropouts in vocational education (Flemish Ministry of Education, 2019). Students in linear education obtain this certificate by completing all the courses; students in modular education obtain this certificate by completing a sufficient number of modules. Although a high school diploma in vocational education is technically only obtained after the completion of an additional specialisation year following 12th grade, in practice, the certificate at the end of 12th grade serves to signify successful completion of a vocational education programme and closely resembles a diploma in other tracks. Therefore, we consider the vocational education certificate to be the outcome of interest. We will refer to this outcome as a diploma in the remainder of this article.

To construct the high school diploma variable, we observe the educational path of each student. First, we determine whether a student obtained a vocational education qualification certificate. This student receives a value of 1 for the high school diploma variable. Students who did not obtain this qualification are considered high school dropouts and receive a value of 0 for the high school diploma variable. Second, we determine the exact year a student left secondary education, either as a high school graduate or as a high school dropout. Lastly, we collapse the dataset to the year of 
school leaving. Thus, although the study initially draws on panel data to observe the entire educational path of students, due to the nature of the outcome variable, we ultimately study a repeated cross-sectional dataset in which each student is either considered a high school graduate or a high school dropout.

It should be noticed that we observe whether students dropped out before 12th grade. If this is the case, these students receive a value of 0 for our high school diploma outcome dummy. Similarly, if students repeated a grade and obtained a diploma after compulsory education (e.g. at age 20), these students receive a value of 1 for our high school diploma outcome. ${ }^{16}$ Finally, we also observe changes between programmes. Thus, if students changed between programmes, we keep following them in the new programme and subsequently observe whether these students obtained a vocational education qualification certificate or not.

For school leavers (graduates and school dropouts) in school year 2010-2011, we also observe quarterly labour market outcomes (employment and earnings). We construct employment as an indicator having value 1 if an individual was employed, and 0 otherwise (if the individual was unemployed or inactive). Further, quarterly earnings are observed to fall within narrow intervals in euros. Following Trostel et al. (2002), we therefore perform the analyses on the logarithm of the midpoints of the intervals.

Control variables. Our data include three individual-level characteristics that we include as control variables. These characteristics are gender, origin and mother's degree. Gender is coded as an indicator having value 1 if the student was male, and 0 if the student was female. We include this variable as gender may be an important moderator of the effect of modular education on both school outcomes and labour market outcomes. For instance, McClune (2001) found that the association between modular education and student achievement was less pronounced for boys than for girls. In addition, the literature has found that the risk of dropout is likely to be higher for boys (Murnane, 2013; Almas et al., 2016). However, boys appear to be earning more than girls (Blau \& Kahn, 2017).

Further, we include two variables to proxy students' socioeconomic status. First, 'origin' is an indicator having value 1 if the student was of foreign origin, and 0 if the student was of Belgian origin. This is calculated based on four characteristics: (a) current nationality; (b) nationality of birth; (c) father's nationality; and (d) mother's nationality. If the answer to one of these traits is foreign and not Belgian, then the student is given a value of 1 on the origin dummy. Second, we include an indicator having value 1 if the student's mother did not finish high school, and 0 if she did. We include these variables because socioeconomic status may be associated with both modular education and outcomes. On the one hand, students in modular education are likely to have a lower socioeconomic status (see Pelleriaux \& De Rick, 2004 for evidence in Flanders). On the other hand, socioeconomic status in general has been found to influence high school dropout and subsequent labour market outcomes (Rumberger \& Palardy, 2005; Holmlund et al., 2011; De Witte et al., 2013; Murnane, 2013). Therefore, to avoid selection bias on observable characteristics, it is important to control for socioeconomic status when relating modular education to school and labour market outcomes. 


\section{Descriptive statistics}

Descriptive statistics are presented in Table 1. The final dataset includes 95,850 students, out of which 51,652 students $(53.89 \%)$ were enrolled in linear programmes and 44,198 students $(46.11 \%)$ were enrolled in programmes that were modularised starting from school year 2008-2009. As mentioned previously, we also observe gender, origin and mother's degree as covariates. As expected, the results indicate that (to become) modular programmes included more students at risk of dropout than linear programmes, both before and after reform. More specifically, (to become) modular programmes included more males, foreign origin students and students whose mother did not finish high school. We correct for these covariates in our model. Finally, before the reform, students in programmes that will become modular had a lower diploma attainment rate than students in programmes that will remain linear, amounting to about 1.8 percentage points. This is expected, as the ministry composed the list of programmes to be modularised based on the high school dropout rates in these programmes. However, after the reform, it appears from Table 1 that although the diploma attainment rate in linear education increased only slightly, the attainment rate in modular education rose sharply. In particular, students in modular education significantly outperformed students in

Table 1. Descriptive statistics

\begin{tabular}{|c|c|c|c|c|c|c|}
\hline & \multicolumn{3}{|c|}{ Before the reform } & \multicolumn{3}{|c|}{ After the reform } \\
\hline & $\begin{array}{l}\text { To } \\
\text { become } \\
\text { modular } \\
\text { education }\end{array}$ & $\begin{array}{l}\text { Linear } \\
\text { education }\end{array}$ & $\begin{array}{l}\text { Difference } \\
\quad(t \text {-test })\end{array}$ & $\begin{array}{l}\text { Modular } \\
\text { education }\end{array}$ & $\begin{array}{l}\text { Linear } \\
\text { education }\end{array}$ & $\begin{array}{l}\text { Difference } \\
\quad(t \text {-test })\end{array}$ \\
\hline \multicolumn{7}{|c|}{ Control variables } \\
\hline $\begin{array}{l}\text { Gender } \\
(1=\text { male })\end{array}$ & 0.537 & 0.469 & $0.068(0.010)^{2}$ & 0.530 & 0.473 & $0.056(0.007)^{2}$ \\
\hline $\begin{array}{l}\text { Origin } \\
(1=\text { foreign })\end{array}$ & 0.121 & 0.102 & $0.019(0.006)^{2}$ & 0.117 & 0.108 & $0.009(0.004)^{3}$ \\
\hline $\begin{array}{l}\text { Mother's } \\
\text { degree } \\
(1=\text { no high } \\
\text { school } \\
\text { diploma) }\end{array}$ & 0.564 & 0.522 & $0.042(0.008)^{2}$ & 0.556 & 0.519 & $0.037(0.005)^{2}$ \\
\hline $\begin{array}{l}\text { Outcome } \\
\text { Diploma }^{1}\end{array}$ & 0.701 & 0.719 & $-0.018(0.005)^{2}$ & 0.753 & 0.725 & $0.028(0.005)^{2}$ \\
\hline Students & \multicolumn{6}{|c|}{$\begin{array}{l}95,850 \\
44,198 \text { in modular education; } 51,652 \text { in linear education }\end{array}$} \\
\hline Programmes & \multicolumn{6}{|c|}{335} \\
\hline Schools & \multicolumn{6}{|l|}{400} \\
\hline
\end{tabular}

${ }^{1}$ Notes: Standard errors are in parentheses.

${ }^{1}$ Diploma ( 1 = diploma, 0 = school dropout $)$ is defined as a vocational education certificate received after successfully completing six grades in linear education or all the required modules in modular education.

${ }^{2}$ Significant at the $1 \%$ level.

${ }^{3}$ Significant at the $5 \%$ level. 
linear education by about 3 percentage points. Thus, our descriptive analysis seems to suggest that modular education had a positive influence on diploma attainment. In the following section, we turn to the difference-in-differences model that aims to establish causality.

\section{Difference-in-differences}

A difference-in-differences identification strategy is employed to compare the differences in diploma attainment among students enrolled in programmes that were modularised with students in programmes that remained linear, before and after the reform period, within schools. Our variation stems from the population of high schools that have been offering both conventional linear programmes and modular programmes after 2008 . The modularisation reform was implemented either immediately in school year 2008-2009 or in consequent school years 2009-2010 or 20102011. Given that we consider the differences within schools, we do not include schools that have been offering only one type of educational programme. This is because within the schools that offered only one type of programme, there is no comparison group to compare the outcomes against. Thus, as there is no variation in the variable of interest within these schools, they are not picked up by the difference-indifferences model. Drawing on Bertrand et al. (2004), the difference-in-differences model is formulated as follows:

$$
y_{i s p t}=\boldsymbol{\alpha}_{s}+\boldsymbol{\theta}_{p}+\gamma_{t}+\beta M_{s p t}+\delta \mathbf{X}_{i s p t}+\varepsilon_{i s p t},
$$

where $y_{i s p t}$ is an indicator for diploma attainment ( 1 is high school diploma, 0 is school dropout) of student $i$, in school $s$, programme $p$ and school year $t$. The variable of interest is $M_{s p t}$, given a value of 1 if a student was enrolled into a modular programme in a given school after the reform. Said otherwise, $M_{s p t}$ is an indicator for whether modular education has affected programme $p$ in school $s$ in school year $t$. Thus, the coefficient $\beta$ estimates the average treatment effect on the treated: the within-school difference in diploma attainment between students in modular and linear education before and after the reform. Depending on the specification, we also include an indicator for gender ( 1 is male, 0 is female), an indicator for origin ( 1 is foreign origin, 0 is Belgian origin) and an indicator for whether the student's mother did not finish high school (1 is no high school diploma, 0 is otherwise) as part of $\boldsymbol{X}_{i s p t}$ in Equation $1 .{ }^{17}$ Finally, $\boldsymbol{\alpha}_{s}, \boldsymbol{\theta}_{p}$ and $\gamma_{t}$ are vectors of school, programme ${ }^{18}$ and school-year fixed effects, respectively. ${ }^{19}$ We cluster standard errors at the school level to account for the dependence of students' outcomes within schools. Nonetheless, clustering at the programme level yields analogous results.

Two points about Equation 1 are worth mentioning. First, we compare diploma attainment between vocational students in programmes that were modularised and programmes that remained linear before and after the reform, per school. For this purpose, we exploit the variation induced by $89 \%$ of the schools offering both modular and linear education simultaneously post-reform. Consequently, given that we include school fixed effects, external shocks during this period would need to have a differential impact on modular and linear programmes within schools. Van 
Landeghem et al. (2012) found that the 2008 financial crisis reduced the risk of high school dropout in Flanders as the labour market prospects for students were lower. Although it is unlikely that the financial crisis had a differential impact on modular and linear programmes, even if this was the case, modular education may dampen the reduced risk of high school dropout as modular programmes are likely less influenced by economic fluctuations than linear programmes (see the section 'Modular education may influence high school dropout'). Thus, we would expect that students in linear education benefit more from the financial crisis in terms of a reduction in high school dropout than students in modular education. As we estimate that modular education reduces high school dropout (see the section 'The effect of modular education on diploma attainment'), our effect would likely be even higher in the absence of the financial crisis. In addition, Van Landeghem et al. (2012) find that although the financial crisis may reduce the risk of high school dropout for boys, girls appear to be unaffected. By contrast, our results indicate that modular education reduces high school dropout for both boys and girls.

Second, $45 \%$ of the schools implemented the reform in school year 2008-2009 (36\% in school year 2009-2010 and 19\% in school year 2010-2011). Given that we observe students until school year 2011-2012, students were able to react to the policy change. Therefore, it is useful to estimate the impact of modular education in the years after (and before) the policy change. In a subsequent analysis, we include leads and lags in our model and estimate the following equation (Autor, 2003):

$$
y_{i s p t}=\boldsymbol{\alpha}_{s}+\boldsymbol{\theta}_{p}+\gamma_{t}+\sum_{t=-q}^{-1} \beta_{i} M_{s p t}+\sum_{t=0}^{m} \beta_{i} M_{s p t}+\delta \mathbf{X}_{i s p t}+\varepsilon_{i s p t},
$$

where $q$ represents the number of leads or anticipatory effects (school years before the reform) and $m$ represents the number of lags or post-treatment effects (school years after the reform). Equation 2 is equivalent to using interactions between our variable of interest, modular education and indicators for school years (Autor, 2003). This allows us to estimate how differences between modular and linear education evolve over time. It should be noted that the model in Equation 2 also assesses the PTA. If the effect is close to zero in the years before the reform, this suggests that the PTA holds (see the section 'PTA and treatment effect by school year').

\section{Results}

This section consists of four subsections. First, we present our difference-in-differences estimates for the effect of modular education on school dropout. In addition to the overall sample, separate estimates for male and female students, on the one hand, and foreign origin and native Belgian students, on the other hand, are presented to relate the results to gender and origin. Second, we estimate the effect of modular education on high school dropout by school year and address the PTA underlying the difference-in-differences model. Third, to test the permeability of the results, we have estimated several alternative specifications and conducted a placebo analysis including a fabricated treatment group. Finally, we estimate the effect of modular education on subsequent labour market outcomes for a part of our sample. 


\section{The effect of modular education on diploma attainment}

Table 2 presents the results of the effect of modular education on diploma attainment. In column (1), we estimate the baseline model without controls. The results suggest that after modular education was implemented, overall diploma attainment increased by 2.4 percentage points (from mean diploma attainment of $72 \%$ ). This suggests a significant positive impact of modular education on diploma attainment. In column (2), we add control variables, namely gender, origin and mother's education. All the coefficients have the expected signs. Male students, foreign origin students and students whose mother did not finish high school have a significantly lower probability of obtaining a vocational education diploma. Nonetheless, the modular education coefficient increases only slightly to 2.5 percentage points. Therefore, we perform the rest of the analysis on the full model with control variables.

In columns (3)-(6), we estimate our difference-in-differences model for males and females, and students from foreign and Belgian origin separately to capture whether the effect of modular education differs by gender and/or by origin. On dividing the sample based on gender, as depicted in columns (3) and (4), it is observed in column (3) that modular education has a significantly positive effect on male students amounting to 2.4 percentage points. The effect of modular education on female students appears larger at 3.5 percentage points. However, a test of equality does not reject the hypothesis of equality of coefficients $(p=0.376)$. Thus, it appears that modular education had a similar significantly positive effect on male and female students.

In columns (5) and (6), we divide the sample by origin. Column (5) indicates that modular education has a large significant positive impact on diploma attainment of students of foreign origin amounting to 7.7 percentage points (from a disturbingly low mean of 58\%). Although the effect of modular education on Belgian students is also positive ( 2 percentage points from a mean of $77 \%$ ), it is not as pronounced as the effect on students of foreign origin. ${ }^{20}$ Thus, it appears from an analysis of the impact of modular education on diploma attainment based on origin as in columns (5) and (6) that modular education may reduce the educational attainment gap between foreign origin students and their native Belgian peers. Given the very low average attainment of foreign origin students, it seems that modular education particularly targets the population of students that are most in need of dropout prevention policy.

\section{PTA and treatment effect by school year}

This difference-in-differences identification strategy relies mainly on the PTA. ${ }^{21}$ This ensures that the difference in diploma attainment of the vocational students before and after modularisation reform is exclusively a result of the implemented educational reform and not a direct consequence of any other observed or unobserved factors. Stated differently, in the absence of the intervention, the dropout rate of the two groups would evolve analogously. We assess the PTA empirically. For this purpose, we include leads (anticipatory effects) and lags (post-treatment effects) in the model as in Equation 2. In the analysis, we omit school year 2005-2006 as the reference school year. 


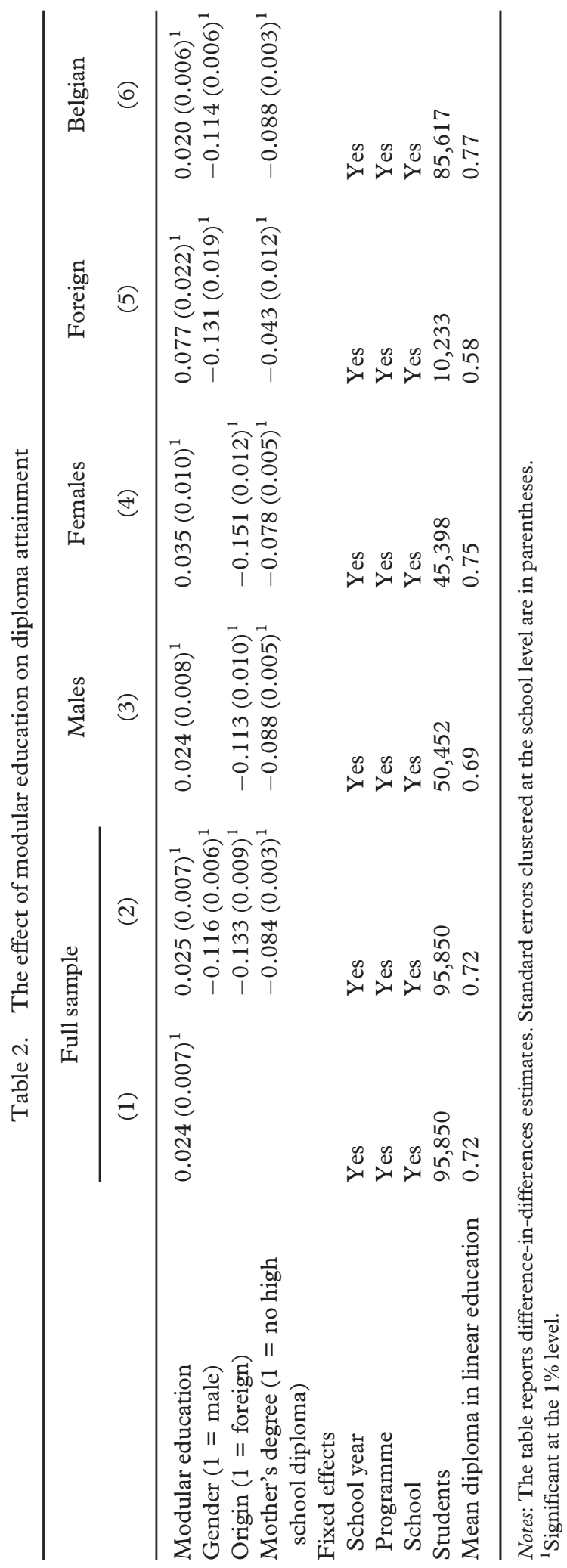


Figure 1 displays the results. We find no evidence of anticipatory effects during the pre-reform period. As the coefficients in school years 2006-2007 and 2007-2008 (prior to the reform) are small and not significantly different from zero, they suggest that the PTA is likely to hold. Further, modular education appears to positively affect diploma attainment in the school year of adoption, 2008-2009. This significantly positive effect of modular education persists in the following three school years. In particular, we observe a significantly positive effect ranging from 2.4 to 3.2 percentage points for the post-reform period. In the first and last observed post-reform school years, the positive effect of modular education appears to be smaller. However, these effects are not significantly different from the other two post-treatment effects $(p=0.319)$. Summarily, we assert-on the basis of our findings- that the PTA is likely to hold and that the positive effect of modular education persists in the years after the introduction of modular education.

\section{Alternative specifications}

In Table 3, we estimate several alternative specifications to verify the internal validity of our results. First, we include programme-specific time trends. Given that modular education was adopted at different points in time, we might wonder whether the treatment effect we observe has absorbed differences between treated units due to an underlying time trend (Besley \& Burgess, 2004). The effect of 2.4 percentage points in column (1) indicates that the inclusion of programme-specific time trends does not

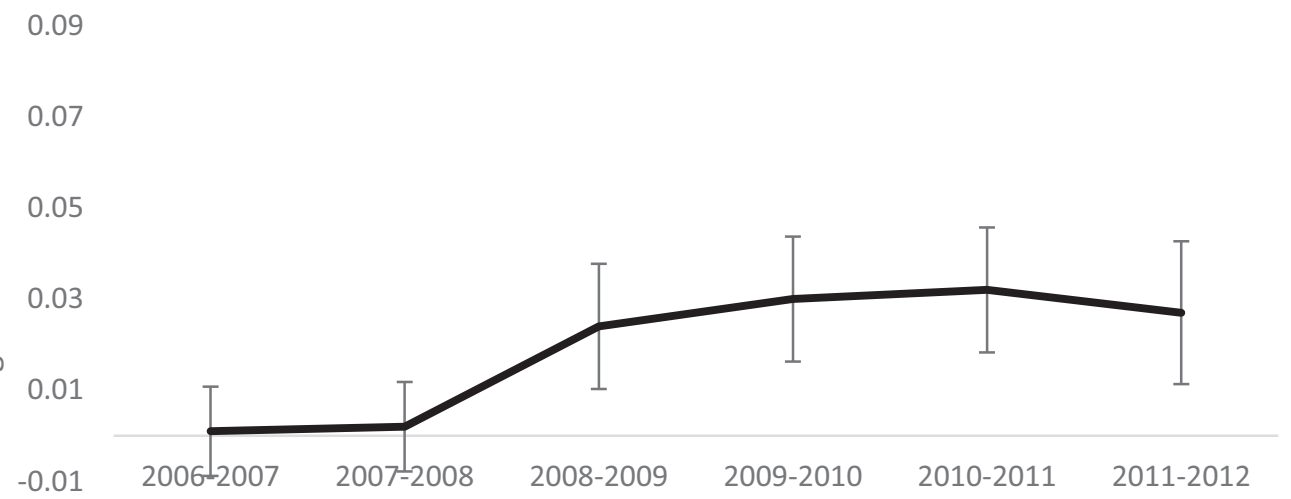

$-0.03$

$-0.05$

School year

Figure 1. Estimated impact of modular education on diploma attainment for years before, during and after adoption of modular education. Notes: School year 2005-2006 has been omitted as the reference school year. Vertical bands represent \pm 1.96 times the standard error of each point estimate. The figure shows no anticipation effect in the school years prior to the reform (2006-2007 and 2007-2008), a positive effect in the school year of adoption (2008-2009) and a persistent

positive effect in subsequent school years (2009-2010, 2010-2011 and 2011-2012) 
Table 3. Alternative specifications

\begin{tabular}{|c|c|c|c|c|}
\hline & $\begin{array}{l}\text { Programme-specific } \\
\text { time trend } \\
\text { (1) }\end{array}$ & $\begin{array}{l}\text { Without } \\
\text { switchers }{ }^{1} \\
\text { (2) }\end{array}$ & $\begin{array}{c}\text { Placebo }^{2} \\
\text { (3) }\end{array}$ & $\begin{array}{c}\text { Exact matching }^{3} \\
\text { (4) }\end{array}$ \\
\hline Modular education & $0.024(0.007)^{4}$ & $0.023(0.006)^{4}$ & $0.004(0.003)$ & $0.030(0.004)^{4}$ \\
\hline Gender $(1=$ male $)$ & $-0.116(0.006)^{4}$ & $-0.115(0.006)^{4}$ & $-0.101(0.005)^{4}$ & \\
\hline Origin $(1=$ foreign $)$ & $-0.133(0.009)^{4}$ & $-0.137(0.009)^{4}$ & $-0.130(0.007)^{4}$ & \\
\hline $\begin{array}{l}\text { Mother's degree } \\
(1=\text { no high } \\
\text { school diploma })\end{array}$ & $-0.084(0.003)^{4}$ & $-0.083(0.003)^{4}$ & $-0.086(0.003)^{4}$ & \\
\hline \multicolumn{5}{|l|}{ Fixed effects } \\
\hline School year & Yes & Yes & Yes & \\
\hline Programme & Yes & Yes & Yes & \\
\hline School & Yes & Yes & Yes & \\
\hline Students & 95,850 & 92,762 & 143,305 & 83,201 \\
\hline
\end{tabular}

${ }^{2}$ Notes: The table reports difference-in-differences estimates. Standard errors clustered at the school level are in parentheses.

${ }^{1}$ Switchers are students who moved from a linear to a modular programme or vice versa.

${ }^{2}$ The placebo analysis compares vocational education students in linear programmes (treatment group) with technical education students in linear programmes (control group). Both groups were not subject to modular education.

${ }^{3}$ Exact matching is performed on control variables used in the initial analysis, namely gender, origin and mother's education, as well as on school.

${ }^{4}$ Significant at the $1 \%$ level.

alter the significantly positive effect of modular education on diploma attainment amounting to 2.5 percentage points obtained in Table 2 .

In the second specification, we consider solely the students who did not switch from modular to linear education or vice versa. As mentioned previously, movement within programmes is uncommon in vocational education. Only $3.22 \%$ of students who were first enrolled in a (to become) modular programme later switched to a linear programme or vice versa. Consequently, the compliance rate with the new reform was likely to be very high. Nonetheless, in column (2) we estimate the difference-indifferences model without the switchers. The effect of modular education on school dropout is, at 2.3 percentage points, very similar to the effect of 2.5 percentage points obtained in the full sample.

A third robustness test includes a placebo analysis to assure that our results are not spurious. A placebo analysis is commonly performed in two distinct ways - by introducing a simulated treatment prior to the real treatment date or by constructing a placebo treatment group. Given that the treatment happened at different points in time, we perform solely the second type of placebo analysis (i.e. we construct a placebo treatment group). If the placebo difference-in-differences estimate is significantly different from zero, the assumptions made are not valid and the difference-in-differences estimates obtained previously are likely to be biased. Consequently, we construct the placebo treatment group by first removing all students enrolled in modular education in the first place. Next, we treat all vocational education students enrolled in linear education as the treatment group. As a control group, we consider students from 
technical education. ${ }^{22}$ These students were not subject to modular education. Consequently, it should be noted that none of the students included in both groups actually received the treatment. In practice, they were all enrolled in linear education. Lastly, we estimate the difference-in-differences model in column (3). As expected, the impact of modular education on diploma attainment using a placebo treatment group, which in practice was not enrolled in modular education, turns out to be close to zero and statistically insignificant. This result also provides a case against sorting of new entrants. If sorting was taking place, the composition change of students in linear vocational education should have induced a placebo treatment effect relative to those in technical education. Our results suggest that this is not the case.

Finally, in the last specification, we perform exact matching before estimating the difference-in-differences model as suggested by Abadie (2005). This technique selects every student who was subject to modular education (as part of the treatment group), and a corresponding student from the control group not subject to modular education but having the exact same values on certain observed characteristics. Thereby, exact matching is applied on variables used in the initial analysis, namely gender, origin and mother's education, as well as on school. We are able to find multiple exact matches for $96 \%$ of the students from the treatment group. Column (4) indicates that exact matching produces a similar effect to the initial result of 2.5 percentage points.

\section{The effect of modular education on labour market outcomes}

In this section, we investigate the impact of modular education on labour market outcomes of students in vocational education after leaving school. However, the impact of modular education on labour market outcomes is calculated solely for school leavers in school year 2010-2011 (we only possess labour market data for these students). As mentioned in the section 'Dataset construction', these individuals are either dropouts or graduates who were enrolled in vocational education in school year 2010-2011 but were no longer enrolled in secondary education in school year 20112012. The labour market outcomes are observed for each quarter after school leaving, starting from Q3 in 2011 (as for the first two quarters of 2011, an individual is still in education) until Q4 in 2013.

The results are summarised in Table 4. It appears from column (1) that students enrolled in modular education programmes are 7.1 percentage points more likely to be employed than students enrolled in linear education (from a baseline employment rate of $67 \%$ ). Moreover, students enrolled in modular education incur $5.5 \%$ more earnings once employed. In Appendix B, we present the effect of modular education on labour market outcomes by quarter. In general, the effect of modular education on employment (Figure B1) remains significantly positive throughout the quarters, with a decreasing trend. The effect of modular education on earnings (Figure B2) also shows a decreasing trend, but loses significance in the last quarter. ${ }^{23}$

By gender, we find a significantly positive effect of modular education on both employment and earnings for both males in column (2) and females in column (3). Although the effect appears to be larger for males, it is only significantly larger for earnings at the $10 \%$ level $(p=0.072)$, and not significantly larger for employment 
Table 4. The effect of modular education on quarterly labour market outcomes for 2010-2011 vocational education school leavers

\begin{tabular}{|c|c|c|c|c|c|}
\hline & $\begin{array}{c}\text { Full sample } \\
\text { (1) }\end{array}$ & $\begin{array}{c}\text { Males } \\
\text { (2) }\end{array}$ & $\begin{array}{c}\text { Females } \\
\text { (3) }\end{array}$ & $\begin{array}{c}\text { Foreign } \\
\text { (4) }\end{array}$ & $\begin{array}{c}\text { Belgian } \\
\text { (5) }\end{array}$ \\
\hline \multicolumn{6}{|l|}{ Outcomes $^{1}$} \\
\hline $\begin{array}{l}\text { Employment } \\
(1= \\
\text { employed })\end{array}$ & $0.071(0.014)^{4}$ & $0.081(0.020)^{4}$ & $0.057(0.019)^{4}$ & $0.072(0.026)^{4}$ & $0.074(0.015)^{4}$ \\
\hline $\begin{array}{l}\text { Log gross } \\
\text { earnings }\end{array}$ & $0.055(0.013)^{4}$ & $0.081(0.020)^{4}$ & $0.040(0.016)^{5}$ & $0.035(0.025)$ & $0.054(0.016)^{4}$ \\
\hline \multicolumn{6}{|l|}{ Fixed effects } \\
\hline $\begin{array}{l}\text { Year } \times \\
\text { quarter }\end{array}$ & Yes & Yes & Yes & Yes & Yes \\
\hline School & Yes & Yes & Yes & Yes & Yes \\
\hline $\begin{array}{l}\text { Additional } \\
\text { controls }^{2}\end{array}$ & Yes & Yes & Yes & Yes & Yes \\
\hline Individuals ${ }^{3}$ & 14,387 & 8,023 & 6,364 & 3,528 & 10,859 \\
\hline
\end{tabular}

Notes: The table reports regression estimates. Standard errors clustered at the school level are in parentheses. Modular education is measured as an indicator having value 1 if a student was enrolled in modular education, and 0 if a student was enrolled in linear education.

${ }^{1}$ Outcomes are observed by quarter, from Q3 in 2011 to Q4 in 2013 (as for the first two quarters of 2011, an individual is still in education).

${ }^{2}$ Control variables include age, gender $(1=$ male $)$, origin $(1=$ foreign $)$ and mother's education $(1=$ no high school diploma).

${ }^{3}$ Earnings are estimated for the sample of employed individuals.

${ }^{4}$ Significant at the $1 \%$ level.

${ }^{5}$ Significant at the $5 \%$ level.

$(p=0.365)$. By origin, columns (4) and (5) show positive coefficients on both employment and earnings for both foreign origin as well as native Belgian individuals. However, the effect on earnings is only significant for natives. This is likely a consequence of the lower sample of foreign origin individuals as a test of equality of coefficients that does not reject the null hypothesis of equal coefficients $(p=0.478)$. In sum, the results suggest that modular education has a positive impact on employment and earnings in the 2 years after leaving high school.

It should be noted that these results are merely suggestive, as we only possess labour market outcomes for individuals who left education in school year 2010-2011. We are, therefore, unable to perform the difference-in-differences analysis, as is the case in previous sections. Moreover, as displayed in Figure 1, the effect of modular education is likely to be higher in 2010-2011 than in the initial school year of adoption (2008-2009). Finally, our results show that the introduction of modular education improved the probability of obtaining a diploma, which may itself lead to higher labour market outcomes. Overall, these results should be interpreted with caution.

\section{Discussion}

This article estimated the effect of modular education on high school dropout. Modular education has been widely used in vocational education and training programmes 
based on the premise that it reduces the school dropout rate significantly. Our results validate and justify this claim, as the current findings suggest that students enrolled in modular education have a lower probability of dropping out than students enrolled in linear education (by 2.5 percentage points from a baseline dropout rate of $28 \%$ ). Thus, our results are in line with most of the previous descriptive and correlational literature that estimated a positive association between modular education and student achievement in general and pre-university education (Taverner \& Wright, 1997; Vidal Rodeiro \& Nàdas, 2012). Moreover, the positive effect of modular education is also similar to the results obtained by Pelleriaux and De Rick (2004), who studied a small pilot project in Flemish vocational education in 2000.

Although the effect appears to be positive for both boys and girls as well as foreign and native Belgian origin students, this positive effect on high school dropout rate is largest for the foreign origin students. In particular, we find that modular education decreases the high school dropout rate by 2 percentage points for native Belgian students and by as much as 7.7 percentage points for foreign origin students (from a disturbingly high baseline dropout rate of $42 \%$ for foreign origin students). Consequently, our results propose that modular education may be an important tool to enable students of foreign origin - who are typically vulnerable to school dropout (Baert \& Cockx, 2013) - to come at par with native Belgian students (without exacerbating the dropout rate of the latter). Modular educational reforms could therefore successfully reduce the large gap in diploma attainment between foreign origin students and local students. Lastly, this study also provides suggestive evidence that modular education has a positive impact on students' employment and earnings up to 2 years after leaving high school. The mechanisms that may explain the positive impact of modular education on diploma attainment are increased flexibility in choice of modules, partial certification and goal-setting. First, in modular education, students enjoy greater flexibility to choose their own educational path in accordance with their interests. Modular education allows students to choose modules that provide them with the highest intrinsic motivation, such that the risk of school dropout is likely to reduce significantly. Second, partial certification may lead to a more frequent experience of success and more feedback, resulting in an enhanced extrinsic motivation for students to continue pursuing a high school degree (Hattie \& Timperley, 2007). This also may explain why the results are primarily driven by the reduction in dropout rates of foreign origin students. These students typically face a difficult socioeconomic home and school environment. A feeling of success induced by partial certification in modular education may increase these students' self-confidence and reduce their dropout significantly. Third, the psychological literature on goal-setting suggests that it may be easier to accomplish a series of short-term goals (such as the completion of each module) than one complex, long-term goal (such as the attainment of a diploma).

Although the above mechanisms suggest that the reduction in high school dropout rate is likely to be beneficial, this may not necessarily be the case for two reasons. First, students may purposely have chosen easier modules to obtain a high school diploma and therefore fragmented their knowledge, resulting in lower educational quality. Second, dropout in vocational education is multi-dimensional and students may be leaving school because they have an opportunity to work in the profession 
they are trained for. By leading to a reduction in high school dropout, modular education may actually have reduced the match between students and their subsequent jobs. Nonetheless, both these mechanisms are unlikely to play a role in our setting. In addition to the effect of modular education on high school dropout, we also estimated the association between modular education and students' labour market outcomes. As we found that modular education increases labour market outcomes, it is likely that the reduction in school dropout rate was beneficial for students.

The present study suffers from three main limitations. First, we only possess labour market outcomes for individuals who left education in school year 2010-2011. We were therefore unable to perform the difference-in-differences analysis for labour market outcomes due to data limitations, unlike for school dropout. Moreover, we did not possess any data on labour market mismatch, which modular education typically attempts to reduce as well. Further, we only possess quantitative data with no complementary qualitative data pertaining to the reasons for such an occurrence. Thus, additional qualitative data should be gathered by means of surveys and interviews with students and staff to investigate the underlying causes of this positive effect. In addition, the relationship between modular education, the financial crisis and high school dropout should be analysed further. Finally, we studied the effect of modular education in vocational education. It would be interesting to investigate whether this effect differs in other educational tracks. Further research should address these issues.

\section{Acknowledgements}

For their helpful comments and suggestions, We would like to thank Dinand Webbink, Fritz Schiltz, Vitezslav Titl, Katleen De Rick, the participants of the Journées Louis-André Gérard-Varet International Conference in Public Economics and the Conference of the European Society for Population Economics, as well as seminar and workshop participants at the London School of Economics and Political Science, Bank of Italy, Humboldt-Universität zu Berlin, University of Lisbon, Universidad de Extremadura, KU Leuven, and Maastricht University. The project leading to this research received funding from the European Union's Horizon 2020 research and innovation programme (Grant No. 691676). Deni Mazrekaj acknowledges funding by the Research Foundation Flanders (FWO) as Aspirant (Grant No. 1172519N). The authors declare that they have no relevant or material financial interests that relate to the research described in this article.

\section{NOTES}

1 Calculated based on youth not in employment, education or training.

2 For the EU, this is a diploma upper secondary education at International Standard Classification of Education Level 3 (Eurostat, 2017). For the USA, a valid credential is either a secondary education diploma or an equivalent credential such as a general education development (GED) certificate (US Department of Education, 2017).

3 Modular secondary education was introduced in France in 1978 (Cedefop, 2015). Since then, modular education has been implemented in other EU countries such as the Netherlands (in 1979), the UK (in 1986), Germany (in the early 1990s), Finland (in 1999), Italy (in 1999), Hungary (in 2006), Portugal (in 2007), Belgium (in 2008) and Latvia (in 2013). 
4 Various models of modular education exist based on the reasons for modularisation activity, drivers and decision-making processes, intensity of modularisation and forms of modular education in practice. However, these models are beyond the scope of this article. For more information, see Pilz (2012) or Li and Pilz (2017).

5 A small pilot modularisation project was implemented in Flanders in 2000 and has been analysed in Pelleriaux and De Rick (2004). Therefore, some of the schools may have implemented modular education already in the experimental phase. We address this issue in the 'Dataset construction' subsection.

6 Around $11 \%$ of schools included only modular or only linear programmes. This was because the list of programmes was determined by the Ministry. Therefore, some schools simply did not offer any of the listed programmes before the reform, while other schools only offered the listed programmes before the reform. After the reform, then, the former schools would continue offering only linear programmes, while the latter schools would be offering only modular programmes. We address this point in the 'Policy reform in vocational education' subsection.

7 Vocational education may include an additional seventh year, see further.

8 The Flemish education system also allows students to combine working and studying from the age of 15 onwards. Students can choose between two tracks. In part-time vocational education (DBSO), students spend at least 2 days in education and spend the rest of the week working for an employer. In learning time (Leertijd), students spend only 1 day in education and 4 days working for an employer.

9 It should be noted that this dropout rate is observed in vocational education in school year 2016-2017. In the period of study, however, namely 2005-2012, the dropout rate in vocational education was around $25 \%$.

10 Bio-aesthetics, hair cutting for men and women, Dutch, French, religion, physical education, arts education and applied economics.

11 It should be noted that under a modular system, there are also requirements on the combination of modules that constitutes a formal qualification. However, most modules are elective modules, which leads to a much higher flexibility of modular education compared to linear education.

12 It is possible that teachers did not fully adapt to the new system. This would lead to our model underestimating the true causal effect of modular education on school dropout.

13 This list includes various vocational programmes in the following fields of study: construction, mechanics/ electricity, bodily care, wood, food, textiles, caretaking, auto, cooling and heat, commerce and graphical techniques.

14 Other reasons for modular education are a better match with the labour market (see below), increased adaptability of the school system to a changing labour environment (modules are easier to update than conventional courses), increasing the (often low) status of vocational education and promoting mobility within the EU (for more information, see Pilz et al., 2018).

15 Although the signalling value of modules may depend on the labour market restrictions in different countries.

16 We decided not to control for grade retention because (a) it may be endogenous to the treatment and (b) it is unclear what grade retention would mean in a modular system as a student cannot 'repeat grade', only a module.

17 We did not include an indicator for birth year due to potential collinearity with the school-year fixed effects. Nonetheless, including an indicator for birth year does not affect the results.

18 The results are also robust to the inclusion of school by programme fixed effects.

19 Estimating the model including district fixed effects leaves the results virtually unchanged.

20 A test of equality of coefficients for foreign origin and native Belgian students rejects the null hypothesis of equality of coefficients $(p=0.009)$.

21 It should be noted that the PTA is a necessary condition to identify the causal effect of modular education on school dropout. To be sufficient, it is required that no relevant time-varying unobserved heterogeneity is present. However, as already stated, no other relevant policies occurred simultaneously. Moreover, we are not aware of any time-varying factors that could influence modular and linear education differently within schools. Therefore, we assume that this condition is likely to hold.

22 Note that the variation stems from schools who offered both the vocational and the technical track.

${ }^{23}$ It should be noted, however, that sample sizes may differ by quarter as the model has been estimated for the sample of employed individuals. Moreover, multiple testing phenomena may play a part. These results should therefore be interpreted with caution.

\section{References}

Abadie, A. (2005) Semiparametric difference-in-differences estimators, Review of Economic Studies, $72(1), 1-19$.

Almas, I., Cappelen, A. W., Salvanes, K. G., Sorensen, E. O. \& Tungodden, B. (2016) What explains the gender gap in college track dropout? Experimental and administrative evidence, American Economic Review: Papers Ev Proceedings, 106(5), 296-302.

Autor, D. H. (2003) Outsourcing at will: The contribution of unjust dismissal doctrine to the growth of employment outsourcing, fournal of Labor Economics, 21(1), 1-42. 
Baert, S. \& Cockx, B. (2013) Pure ethnic gaps in educational attainment and school to work transitions: When do they arise?, Economics of Education Review, 36, 276-294.

Balestra, S. \& Backes-Gellner, U. (2017) Heterogeneous returns to education over the wage distribution: Who profits the most?, Labour Economics, 44, 89-105.

Bertrand, M., Duflo, E. \& Mullainathan, S. (2004) How much should we trust differences-in-differences estimates?, Quarterly fournal of Economics, 119(1), 249-275.

Besley, T. \& Burgess, R. (2004) Can labor regulation hinder economic performance? Evidence from India, Quarterly fournal of Economics, 119(1), 91-134.

Black, S. E., Devereux, P. J. \& Salvanes, K. G. (2008) Staying in the classroom and out of the maternity ward? The effect of compulsory schooling laws on teenage births, Economic fournal, $118,1025-1054$.

Blau, F. D. \& Kahn, L. M. (2017) The Gender Wage Gap: Extent, Trends, and Explanations, Fournal of Economic Literature, 55, 789-865.

Cairo, I. \& Cajner, T. (2018) Human capital and unemployment dynamics: Why more educated workers enjoy greater employment stability, Economic foumal, 128(609), 652-682.

Cassady, J. C. \& Johnson, R. E. (2002) Cognitive test anxiety and academic performance, Contemporary Educational Psychology, 27(2), 270-295.

Cedefop (2015) The role of modularisation and unitisation in vocational education and training. Working Paper No. 26 (Luxembourg, Publications Office).

Chankseliani, M., Relly, S. J. \& Laczik, A. (2016) Overcoming vocational prejudice: How can skills competitions improve the attractiveness of vocational education and training in the UK?, British Educational Research fournal, 42(4), 582-599.

Cook, P. J. \& Kang, S. (2016) Birthdays, schooling, and crime: Regression-discontinuity analysis of school performance, delinquency, dropout, and crime initiation, American Economic fournal: Applied Economics, 8(1), 33-57.

De Bruijn, E. \& Howieson, C. (1995) Modular vocational education and training in Scotland and The Netherlands: Between specificity and coherence, Comparative Education, 31(1), 83-99.

De Witte, K. \& Mazrekaj, D. (2016) Vroegtijdig schoolverlaten in het (deeltijds) beroepsonderwijs [School dropout in (part-time) vocational education], Over. Werk: Tijdschrift van het Steunpunt Werk, 26(1), 111-119.

De Witte, K., Cabus, S., Thyssen, G., Groot, W. \& Maassen van den Brink, H. (2013) A critical review of the literature on school dropout, Educational Research Review, 10, 13-28.

Devereux, P. J. \& Hart, R. A. (2010) Forced to be rich? Returns to compulsory schooling in Britain, Economic fournal, 120, 1345-1364.

Dickson, M. \& Harmon, C. (2011) Economic returns to education: What we know, what we don't know, and where we are going - some brief pointers, Economics of Education Review, 30(6), 1118-1122.

Dolton, P. \& Sandi, M. (2017) Revisiting the British education evidence, Labour Economics, 48, 87104.

Ertl, H. (2000) Modularisation of vocational education in Europe: NVQs and GNVQs as a model for the reform of initial training provisions in Germany? (Oxford, Symposium Books).

Eurofound (2012) NEETs: Young people not in employment, education or training: Characteristics, costs and policy responses in Europe (Dublin, Eurofound).

European Commission (2013) Reducing early school leaving: Key messages and policy support (Brussels, European Commission).

Eurostat (2017) Early leavers from education and training (Luxembourg, Sage).

Flemish Ministry of Education (2015) Experimenteel secundair onderwijs volgens een modulair stelsel [Experimental secondary education according to a modular system]. Available online at: http://data-onderwijs.vlaanderen.be/edulex/document.aspx?docxml:id=13995 (accessed 1 August 2019).

Flemish Ministry of Education (2019) Vroegtijdig schoolverlaten in het Vlaams secundair onderwijs. Cijferrapport voor de schooljaren 2011-2012 tot en met 2016-2017 [School dropout in Flemish secondary education. Report for the school years 2011-2012 until 2016-2017]. 
Available online at: https://www.vlaanderen.be/publicaties/vroegtijdig-schoolverlaten-in-hetvlaams-secundair-onderwijscijferrapport-voor-de-schooljaren-2011-2012-tot-en-met-20162017 (accessed 1 August 2019).

Grebe, T. \& Ekert, S. (2017) The training module concept: A way towards quality improvement and inclusion in German Vocational Education and Training (VET)?, in: M. Pilz (Ed.) Vocational education and training in times of economic crisis: Lessons from around the world (Cham, Springer International), 369-387.

Groot, W. \& van den Brink, H. M. (2007) The health effects of education, Economics of Education Review, 26(2), 186-200.

Hattie, J. \& Timperley, H. (2007) The power of feedback, Review of Educational Research, 77(1), $81-112$.

Hayward, G. \& McNicholl, J. (2007) Modular mayhem? A case study of the development of the Alevel science curriculum in England, Assessment in Education: Principles, Policy E Practice, 14 (3), 335-351.

Hennessy, E., Hernandez, R., Kieran, P. \& MacLoughlin, H. (2010) Teaching and learning across disciplines: Student and staff experiences in a newly modularized system, Teaching in Higher Education, 15(6), 675-689.

Hodgson, A. \& Spours, K. (2003) Beyond A levels: Curriculum 2000 and the reform of 14-19 qualifications (London, Kogan Page).

Holmlund, H., Lindahl, M. \& Plug, E. (2011) The causal effect of parents' schooling on children's schooling: A comparison of estimation methods, Fournal of Economic Literature, 49(3), 615-651.

Li, M. (2006) High school completion and future youth unemployment: New evidence from high school and beyond, fournal of Applied Econometrics, 21(1), 23-53.

Li, J. \& Pilz, M. (2017) Modularisation in the German VET system: A study of policy implementation, Fournal of Education and Work, 30(5), 471-485.

Locke, E. \& Latham, G. P. (2002) Building a practically useful theory of goal setting and taks motivation: A 35-year odyssey, American Psychologist, 57(9), 705-717.

Mazrekaj, D., De Witte, K. \& Vansteenkiste, S. (2019) Labour market consequences of a high school diploma, Applied Economics, 51(21), 2313-2325.

McClune, B. (2001) Modular A-levels - who are the winners and losers? A comparison of lowersixth and upper-sixth students' performance in linear and modular A-level physics examinations, Educational Research, 43(1), 79-89.

Merlo, A. \& Wolpin, K. I. (2015) The transition from school to jail: Youth crime and high school completion among black males, European Economic Review, 79, 234-251.

Murnane, R. J. (2013) U.S. high school graduation rate patterns and explanations, fournal of Economics Literature, 51(2), 370-422.

Oreopoulos, P. (2007) Do dropouts drop out too soon? Wealth, health and happiness from compulsory schooling, Fournal of Public Economics, 91, 2213-2229.

Oreopoulos, P. \& Salvanes, K. G. (2011) Priceless: The nonpecuniary benefits of schooling, fournal of Economic Perspectives, 25(1), 159-184.

Pelleriaux, K. \& De Rick, K. (2004) Evaluatie van het experiment modularisering in het secundair onderwijs [Evaluation of the modularisation experiment in secondary education] (Antwerpen/Leuven, Universiteit Antwerpen/K.U. Leuven).

Pilz, M. (2012) Modularisation of vocational training in Germany, Austria and Switzerland: Parallels and disparities in a modernisation process, fournal of Vocational Education and Training, 64 (2), 169-183.

Pilz, M., Li, J., Canning, R. \& Minty, S. (2018) Modularisation approaches in initial vocational education: Evidence for policy convergence in Europe?, fournal of Vocational Education and Training, 70(1), 1-26.

Priestley, M. (2003) Curriculum 2000: A broader view of A levels, Cambridge fournal of Education, 33(2), 237-255.

Rumberger, R. W. \& Palardy, G. J. (2005) Test scores, dropout rates, and transfer rates as alternative indicators of high school performance, American Educational Research fournal, 42(1), $3-42$. 
Rust, C. (2000) An opinion piece: A possible student-centered assessment solution to some of the current problems of modular degree programs, Active Learning in Higher Education, 1(2), 126131.

Somers, M. A., Cabus, S. J., Groot, W. \& van den Brink, M. (2019) Horizontal mismatch between employment and field of education: Evidence from a systematic literature review, fournal of Economic Surveys, 33(2), 567-603.

Spence, M. (1973) Job market signaling, Quarterly fournal of Economics, 87(3), 355-374.

Taverner, S. \& Wright, M. (1997) Why go modular? A review of modular A-level mathematics, Educational Research, 39(1), 104-112.

Thomas, G. (1993) Some reactions to the teaching of science using a modular scheme, Educational Review, 45(3), 213-226.

Trostel, P., Walker, I. \& Woolley, P. (2002) Estimates of the economic return to schooling for 28 countries, Labour Economics, 9(1), 1-16.

US Department of Education (2017) The condition of education 2016: Status dropout rates (Washington, D.C., National Center for Education Statistics).

Van Houtte, M. \& Stevens, P. A. J. (2015) Tracking and sense of futility: The impact of betweenschool tracking versus within-school tracking in secondary education in Flanders (Belgium), British Educational Research Fournal, 41(5), 782-800.

Van Landeghem, G., De Fraine, B., Gielen, S. \& Van Damme, J. (2012) Vroege schoolverlaters in Vlaanderen tot 2010: Een analyse van de invloed van de financieel-economische crisis van 2008 [School dropouts in Flanders until 2010: An analysis of the influence of the financial-economic crisis of 2008] (Leuven, Steunpunt SSL).

Vidal Rodeiro, C. L. \& Nàdas, R. (2012) Effects of modularity, certification session and re-sits on examination performance, Assessment in Education: Principles, Policy E Practice, 19(4), 411430.

Wilde, S., Wright, S., Hayward, G., Johnson, J. \& Skerrett, R. (2006) Nuffield review higher education focus groups: Preliminary report (Oxford, University of Oxford).

\section{Appendix A}

Table A1. School characteristics by type of education offered

\begin{tabular}{|c|c|c|c|}
\hline & $\begin{array}{c}\text { Modular and linear } \\
\text { (1) }\end{array}$ & $\begin{array}{c}\text { Only modular } \\
\text { (2) }\end{array}$ & $\begin{array}{c}\text { Only linear } \\
\text { (3) }\end{array}$ \\
\hline Number of students & 543 & $639^{1}$ & $477^{1,2}$ \\
\hline Students with mother without degree & 0.362 & $0.410^{1}$ & $0.274^{1,2}$ \\
\hline Students who do not speak Dutch at home & 0.134 & $0.299^{1}$ & $0.073^{1,2}$ \\
\hline Students with social assistance & 0.335 & $0.404^{1}$ & $0.288^{1,2}$ \\
\hline Students from poor neighbourhood & 0.287 & $0.401^{1}$ & $0.227^{1,2}$ \\
\hline Diploma attainment & 0.727 & $0.592^{1}$ & $0.753^{1,2}$ \\
\hline Number of schools & 400 & 10 & 42 \\
\hline
\end{tabular}

\footnotetext{
${ }^{1}$ The coefficient is significantly different from the baseline coefficient of modular and linear education in column (1) at the $5 \%$ level using a $t$-test.

${ }^{2}$ The coefficient is significantly different from the baseline coefficient of only modular education in column (2) at the $5 \%$ level using a $t$-test.
} 
Table A2. School characteristics by implementation school year for schools used in the withinschool analysis

\begin{tabular}{lccc}
\hline & $2008-2009$ & $2009-2010$ & 2010-2011 \\
& $(1)$ & $(2)$ & $(3)$ \\
\hline Number of students & 595 & $530^{1}$ & $476^{1,2}$ \\
Students with mother without degree & 0.396 & $0.353^{1}$ & $0.301^{1,2}$ \\
Students who do not speak Dutch at home & 0.182 & $0.145^{1}$ & $0.101^{1,2}$ \\
Students with social assistance & 0.340 & 0.336 & $0.323^{1,2}$ \\
Students from poor neighbourhood & 0.312 & $0.295^{1}$ & $0.269^{1,2}$ \\
Diploma attainment & 0.698 & $0.731^{1}$ & $0.755^{1,2}$ \\
Number of schools & 179 & 144 & 77 \\
\hline
\end{tabular}

Notes: These schools offered only linear programmes before the reform, and both linear and modular programmes after the reform.

${ }^{1}$ The coefficient is significantly different from the baseline coefficient of school year 2008-2009 in column (1) at the $5 \%$ level using a $t$-test.

${ }^{2}$ The coefficient is significantly different from the baseline coefficient of school year 2009-2010 in column (2) at the $5 \%$ level using a $t$-test.

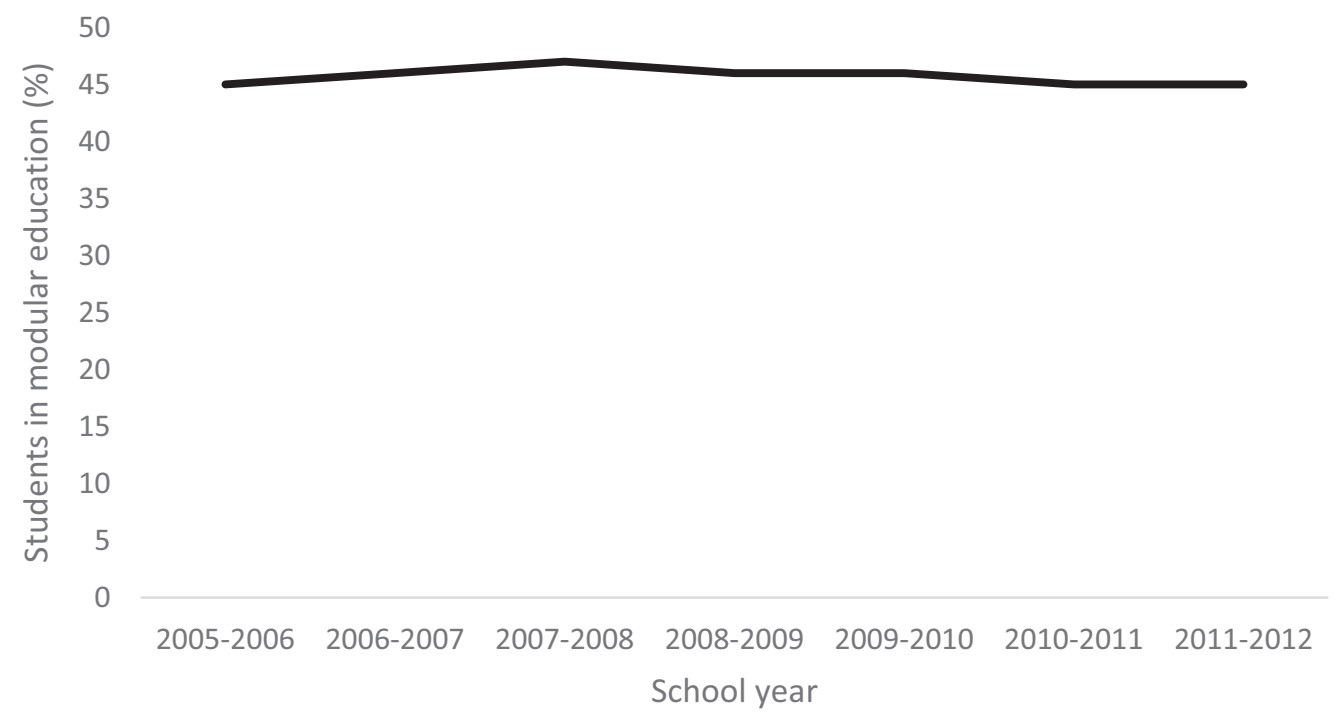

Figure A1. Students in (to become) modular education by school year. Notes: The figure shows that the share of students in (to become) modular education has remained stable at about $46 \%$ before and after the introduction of modular education, which started in school year 2008-2009 


\section{Appendix B}

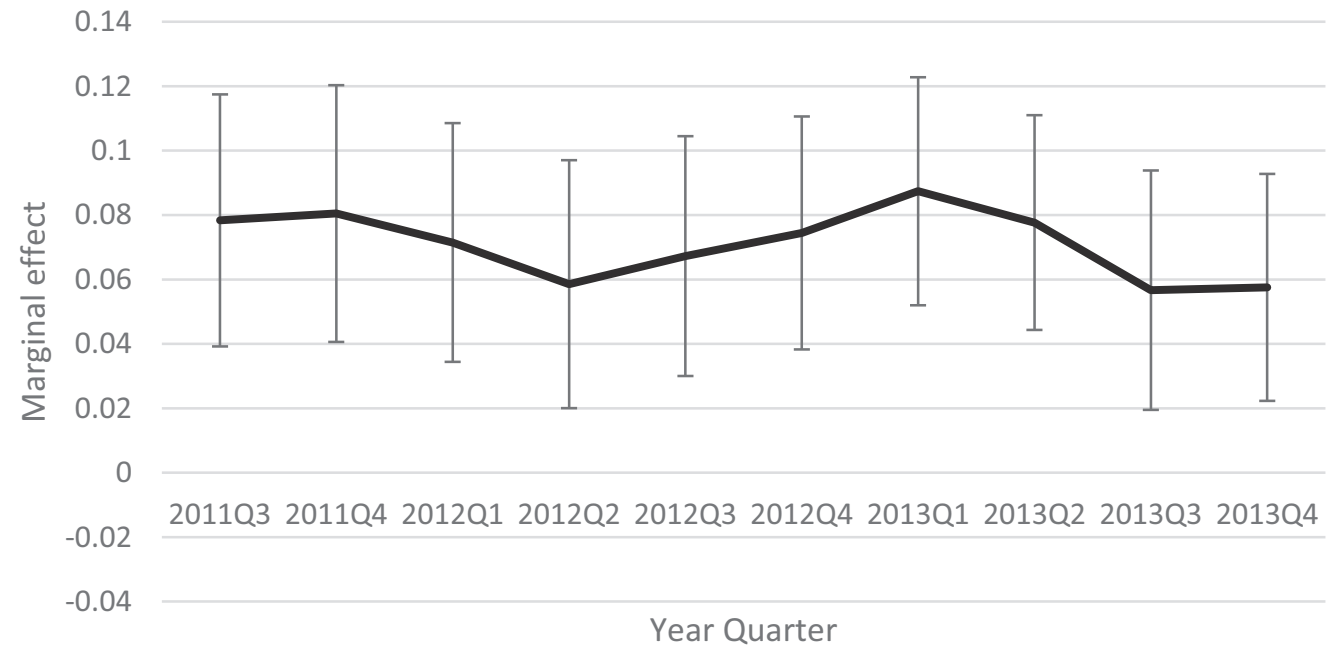

Figure B1. The effect of modular education on employment for 2010-2011 vocational education school leavers by quarter. Notes: The figure reports regression estimates. Vertical bands represent \pm 1.96 times the standard error of each point estimate. Modular education is measured as an indicator having value 1 if a student was enrolled in modular education, and 0 if a student was enrolled in linear education. Employment is measured as an indicator having value 1 if the individual was employed, and 0 otherwise. The model includes school and year by quarter fixed effects as well as controls for gender, origin and mother's education

\subsection{4}

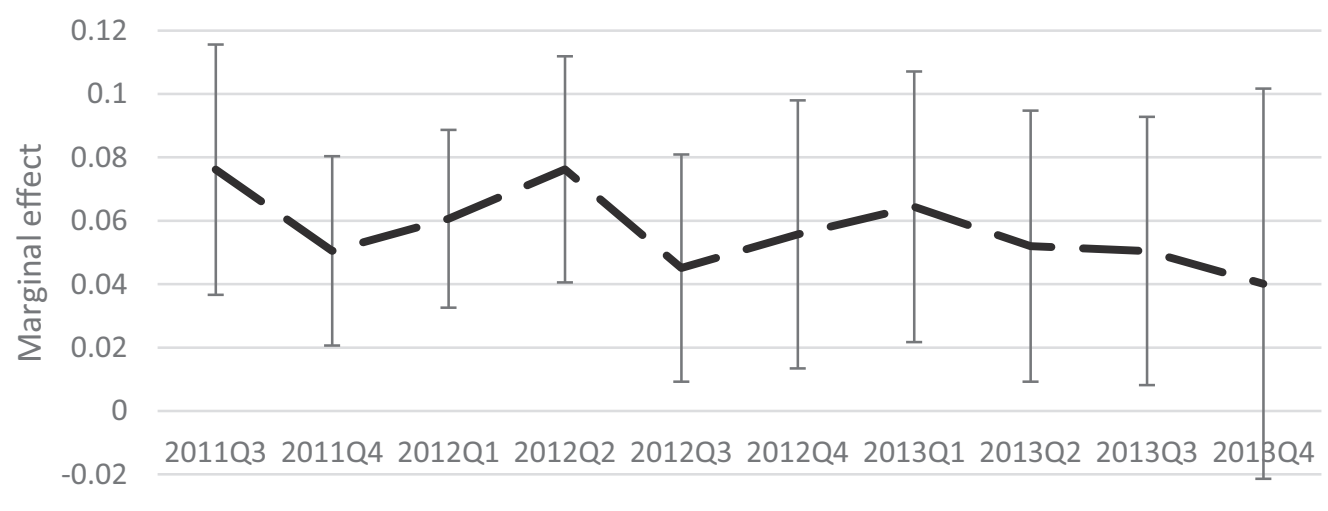

$-0.04$

\section{Year Quarter}

Figure B2. The effect of modular education on log gross earnings for 2010-2011 vocational education school leavers by quarter. Notes: The figure reports regression estimates. Vertical bands represent \pm 1.96 times the standard error of each point estimate. Modular education is measured as an indicator having value 1 if a student was enrolled in modular education, and 0 if a student was enrolled in linear education. The model includes school and year by quarter fixed effects as well as controls for gender, origin and mother's education. The model is estimated for the sample of employed individuals 